\title{
DEVELOPMENT OF BIOTHENOLOGICAL METHODS FOR USING PROOXIDANT-ANTIOXIDANT PROPERTIES OF MEDICINAL MUSHROOMS ${ }^{1}$
}

\author{
Fedotov O. V., Usikova Z. L.
}

\section{INTRODUCTION}

Basidium mushrooms are a source of various natural biologically active substances with a wide range of practical applications. They're used as diets, food additives, medicinal mushrooms, bio-preparations for plant protection and cosmetics. The relevance of the study of basidium fungi due to the establishment of their useful properties, the search for new chemical compounds, the study of patterns and directional regulation of the metabolic pathways of biologically active substances, the determination of the biological role of active metabolites, in particular in the adaptation to a variety of substrates and adaptogens and adaptations, ecology and economy. Development of new intensive biotechnologies for cultivation of different types of basidium mushrooms with the purpose of obtaining both mycelium and biologically active compounds is becoming more relevant every year ${ }^{2}$.

The development of new biotechnologies requires a deep study of the factors that regulate the biosynthetic functions of fungal cells and maximize their potential. Adaptation consist in changing the balance of the prooxidantantioxidant system: activation of lipid peroxidation processes and enzyme systems, formation of prooxidant-antioxidant substances capable of actively responding to the action of certain factors. Functionally labile antioxidant substances include oxidative-reduction catolasis enzymes (EC number: EC

${ }^{1}$ We are grateful to the scientific staff of the Department of Mycology of the M.G. Kholodny of Institute of Botany of the National Academy of Sciences of Ukraine for cooperation, provided materials of the IBK Mushroom Culture Collection, which has the status of the National property of Ukraine (Федотов O.В., Чайка O.В., Волошко Т.Є., Велигодська А.К. Колекція культур шапинкових грибів - основа мікологічних досліджень та стратегії збереження біорізноманіття базидіоміцетів Вісник Донеиького університету, Сер. А: Природничі науки. 2012. 1. С. 209-213. URL: http://jvestnik-a.donnu.edu.ua/article/viewFile/4991/5024).

2 Федотов О.В., Чайка О.В., Волошко Т.Є., Велигодська А.К. Колекція культур шапинкових грибів - основа мікологічних досліджень та стратегії збереження біорізноманіття базидіоміцетів. Вісник Донецького університету, Сер. А: Природничі науки. 2012. 1. С. 209-213. URL: http://jvestnik-a.donnu.edu.ua/ article/viewFile/4991/5024 
1.11.1.6), superoxides (EC 1.15.1.1), peroxides (EC 1.11.1.7), polyphenols, pigments and others ${ }^{3}$.

Xylotrophic basidiomycotic mushrooms is capable of forming highly active oxygen radicals, which are involved in the destruction of macromolecular substances, primarily phenolic compounds, lignin, cellulose and etc. It is envisaged that studying the mechanisms of such destruction may open the way to the development of environmentally friendly energysaving biotechnologies, biodegradation and bio-utilization of chemically stable industrial waste and processing of lignocellulosic raw materials. Of great importance in the process of degradation of lignin by xylotrophs are the reactions of free-radical oxidation, as well as the synthesis by these fungi of various oxidative substances and bioantioxidants. At the same time, the relationship between pigmentation and secondary metabolites formation, antioxidant and genoprotective properties of mushroom pigments carotenoids and melanin, is researched.

Detailed researches of medicinal mushrooms show that their physiological effects can be largely due to the presence of antioxidant compounds and their balance in the system of prooxidant antioxidants. However, data on the prooxidant-antioxidant activity of basidium mushrooms are fragmentary and single, there is a lack of systematic research of the antioxidant properties of the biologically active compounds of these fungi. Research has just begun on the use of basidiomycotic in environmental mycotesting.

Thus, information on the physiological activity of medicinal mushrooms will make it possible to assess the biotechnological potential of these organisms and will open the prospects for their use in industry, ecology and medicine, will serve as a basis for production new generation drugs, various food additives and functional products of mushroom origin.

\section{Antioxidant activity of enzymatic preparations of fungal origin}

Research of the prooxidant-antioxidant activity of the basidium mushrooms strains showed that biologically active substances, including antioxidants (for example, a low-molecular compound - ergothionein), synthesized in mycelium cells, are transferred to the culture filtrate. We can assume that these substances also enter the mushroom preparations when they are obtained from the crop fluid or vegetative mycelium.

In order to test this hypothesis, we determined the antioxidant activity of the 21 enzyme preparations of mushroom origin (Table 1) obtained, different

3 Федотов О.В. Біотехнологічні засади регулювання i використання прооксидантно-антиоксидантної активності базидієвих грибів : дис. ... д-ра біол. наук : 03.00.20. Київ, 2018. 327 с. 
types of activity: MCA - milk-clotting activity ${ }^{4}, \mathrm{PA}-$ peroxidase activity $^{5}$ and CA - catalase activity ${ }^{6,7}$, obtained for certain purposes ${ }^{8,9,10}$. When AOA enzyme preparations were determined, their concentration in aqueous solution was $0.01 \mathrm{~g} / \mathrm{cm}^{3}$.

The results of the research showed that enzyme preparations (EP) of mushroom differs significantly in the level of AOA, which is reliably unrelated to protein content in products. Also, the AOA of enzyme preparations do not correlate with such activity of the source mycological material. Probably, the AOA of the culture filtrates is due to the presence in their composition of various substances (eg. glutathione, proline, etc.; the interaction of proline with antioxidant enzymes is still not fully understood) and low molecular weight AO substances (eg, ergothionein and others), quickly get into mushroom preparations.

The highest AOA value is the enzyme preparation from strain M-250 of the fungus Tyromyces undosus, followed by the descending order of AOA values of strain B-046 Mycoleptodon ochracens, B-059 and M-253 Irpex lacteus.

For EP of strain B-004 Sparassis crispa and strain C-070 Tyromyces undosus recorded oxidative activity, this is opposite to AOA and is due to the advantage in their composition of oxidizing substances. Therefore, both maximum and minimum AOA values are recorded in EP of Polyporous mushrooms.

${ }^{4}$ Fedotov O.V., Velygodska A.K. Milk-clotting and antioxidant activity of enzyme preparations of fungi strains of the order Polyporales s.l. The scientific heritage. Biological Sciences. 2016. V.1. № 2(2). P. 71-76.

5 Voloshko T.E., Fedotov O.V. Active producers of peroxidase Basidiomycetes strains screening. Biotechnologia Acta. 2013. № 6(5). P. 137-142. URL: http://oaji.net/articles/ 2017/5931-1520253769.pdf

6 Voloshko T.E., Fedotov O.V. Comparative characteristics of basidiomycetes producers of catalase. Biotechnologia Acta. 2013. № 6(3). P. 89-94.

${ }_{7}^{7}$ Федотов О.В., Волошко Т.Є. Розробка способів отримання і аналіз ферментних препаратів пероксидаз та каталаз деяких видів базидіоміцетів. Біологічний вісник Мелітопольського державного педагогічного університету ім. Богдана Хмельницького. 2013. № 1(7). С. 113-127. URL: http://nbuv.gov.ua/UJRN/ bvmd_2013_1_12

8 Федотов О.В. Амінокислотний склад ферментних препаратів каталази їстівних лікарських грибів Flammulina velutipes i Pleurotus ostreatus. Вісник Донеиького університету. Сер. А: Природничі науки. 2005. 2. С. 247-250.

Федотов О. В. Амінокислотний склад ферментних препаратів пероксидаз їстівних лікарських грибів Lentinus edodes, Flammulina velutipes i Pleurotus ostreatus. Вісник Донецького університету. Сер. А: Природничі науки. 2006. 2. С. 270-274.

${ }^{10}$ Fedotov O. V., Velygodska A. K. Milk-clotting and antioxidant activity of enzyme preparations of fungi strains of the order Polyporales s. 1. The scientific heritage. Biological Sciences. 2016. V. 1. 2(2). P. 71-76. 
Table 1

Antioxidant activity of enzyme preparations derived from mycelium (MG) or culture filtrate (CF) of certain types of basidium fungi

\begin{tabular}{|c|c|c|c|c|}
\hline Species & Strain & $\begin{array}{c}\text { EP, activity type } \\
\text { (origin) }\end{array}$ & $\begin{array}{c}\text { Protein } \\
\text { content, \% }\end{array}$ & AOA, \% \\
\hline \multicolumn{5}{|c|}{ Order Polyporales } \\
\hline Amyloporia lenis & $\mathrm{A}-004$ & $\mathrm{MCA}(\mathrm{CF})$ & 43.63 & 56.08 \\
\hline Chaetoporus ambiquus & B-062 & MCA (CF) & 33.20 & 80.24 \\
\hline Fibuloporia mollusca & $\mathrm{A}-020$ & $\mathrm{MCA}(\mathrm{CF})$ & 17.37 & 24.19 \\
\hline \multirow{3}{*}{ Irpex lacteus } & B-059 & $\mathrm{MCA}(\mathrm{CF})$ & 39.11 & 90.80 \\
\hline & $\mathrm{M}-232$ & MCA (CF) & 34.07 & 16.89 \\
\hline & M-253 & MCA (CF) & 33.76 & 86.73 \\
\hline Laeticorticium roseum & $\mathrm{P}-330$ & $\mathrm{MCA}(\mathrm{CF})$ & 20.74 & 52.98 \\
\hline Mycoleptodon ochracens & B-046 & MCA (CF) & 41.17 & 92.63 \\
\hline Sparassis crispa & Б-004 & MCA (CF) & 32.50 & -42.80 \\
\hline Tyromyces lacteus & A-027 & MCA (CF) & 37.12 & 46.30 \\
\hline Tyromyces revolutus & $\mathrm{A}-025$ & MCA (CF) & 36.20 & 39.51 \\
\hline \multirow{2}{*}{ Tyromyces undosus } & $\mathrm{M}-250$ & $\mathrm{MCA}(\mathrm{CF})$ & 29.60 & 94.78 \\
\hline & $\mathrm{C}-070$ & MCA (CF) & 31.05 & -62.85 \\
\hline \multicolumn{5}{|c|}{ Order Agaricales } \\
\hline \multirow{3}{*}{ Flammulina velutipes } & F-vv & $\mathrm{CA}(\mathrm{CF})$ & 55.83 & 19.10 \\
\hline & F-vv & PA (MG) & 50.49 & 10.50 \\
\hline & F-vv & PA (CF) & 39.63 & 11.00 \\
\hline \multirow{2}{*}{ Lentinula edodes } & 523 & PA (MG) & 39.72 & 5.45 \\
\hline & 523 & PA (CF) & 20.06 & 14.00 \\
\hline \multirow{3}{*}{ Pleurotus ostreatus } & $\mathrm{P}-01$ & $\mathrm{CA}(\mathrm{CF})$ & 57.07 & 13.85 \\
\hline & $\mathrm{P}-01$ & PA (MG) & 37.82 & 6.80 \\
\hline & P-01 & PA (CF) & 42.41 & 16.50 \\
\hline
\end{tabular}

EP strains of agaric fungi Flammulina velutipes, Lentinula edodes and Pleurotus ostreatus, significantly - 5-7 times inferior to the level of AOA named strains M-250, B-046 and B-059 polypore mushrooms. The enzyme preparations derived from the mycelium have even less activity compared to EP obtained from the culture fluid.

Thus, the recorded data of AOA of enzyme preparations probably correspond to the not initial total content of bioantioxidants (enzymes, pigments, etc.) in the mycological material from which they were derived. They are directly dependent on the protein content of the antioxidants and the rate of diffusion of the low molecular weight antioxidants into the preparation. Obtained data from AOA of mushroom preparations indicate the need for such analysis of all mushroom products for a more complete evaluation of its properties ${ }^{11,12}$.

11 Федотов О.В. Загальна антиоксидантна активність деяких штамів базидіальних грибів в динаміці росту. Біологічний вісник Мелітопольського державного педагогічного університету ім. Богдана Хмельницького. 2016. № 2(6). С. 158-165. 


\section{Development of a method for bioindication of the state of the environment using indicators of prooxidant-antioxidant system of basidiomycetes}

Environmental pollution is complex problem involves the introduction of new, non-specific physical, chemical or biological factors to the natural level. Such changes are, in the vast majority of cases, undesirable with negative effects on wildlife. The multifactorial pollution increases the task of improving existing and developing new methods of environmental testing. Such methods should capture not only the appearance and level of these or other factors, but also reveal in an integral form the degree and intensity of their complex impact on the biota. Biological methods for identifying and monitoring the state of the environment meet these requirements ${ }^{13}$.

Methods have been developed and the efficiency of using as bioindicators of organisms from different systematic groups is shown. Recently, representatives of the wild mushroom kingdom have been involved in these researches. In particular, high sensitivity to changes in environmental conditions of xylotrophic basidiomycotic was detected.

It is known that the indicator properties of biological objects can manifest themselves at different levels of biota organization morphological, biocenotic, chemical, physiological, etc. For example, homeostasis, physiological state, and ability to adapt to aerobic organisms are determined by the steady development of a prooxidant-antioxidant balance - the interaction of active oxygen forms and antioxidants. Violation of this balance towards the activation of lipid peroxidation processes and reduction of antioxidant protection leads to the development of certain pathological conditions, the development of stress response to environmental factors and is the trigger of certain mechanisms of protection. The rate of formation and accumulation of prooxidants is balanced at a certain level by the synthesis and activity of endo- and exogenous antioxidants. The concept of antioxidant status is used to characterize organisms or their states. The practical use of indicators of the predoxidant-antioxidant system of organisms in many practical areas, in particular in the indication of biotechnological processes and the state of the environment, is interesting ${ }^{14,15}$.

12 Федотов О.В. Біотехнологічні засади регулювання i використання прооксидантно-антиоксидантної активності базидієвих грибів : дис. ... д-ра біол. наук : 03.00.20. Київ, 2018. 327 с.

Федотов О.В., Євсєєнкова А.М., Перцевой М.С. Активність ПОЛ і каталази макроміцетів - як можливі біоіндикаційні показники екологічного стану їх місця зростання. Збірник наукових пращь Луганського начіонального аграрного університету. Сер. «Сільськогосподарські науки». 2008. № 82. С. 73-81.

${ }^{14}$ Федотов О.В. Фізико-хімічні показники мікологічних об'єктів у біоіндикації довкілля. Проблеми екологї̈ та охорони природи техногенного регіону. 2011. № 1(11). C. 261-265. 
To assess of the environment state, a test system based on the cultivation of a specific test object under clearly defined conditions, which differ in one factor only - a plant substrate with unpolluted and technogenically transformed media, with further determination and comparison of the antioxidant status of the antioxidant system test object. This avoids the influence of environmental factors and investigates the response of a test object to one or a complex effect of pollution factors.

Plants' ability to bioaccumulate ecotoxicants such as heavy metals is well known and is the basis for phytoremediation of contaminated media. Unlike mushrooms, which accumulate toxicants mainly from the substrate, and mosses and lichens - from the atmosphere, vascular plants are able to accumulate elements and respond to factors simultaneously from several media. Thus, plants are different from the above organisms and are special concentrators of ecotoxicants. So the use of both plants and xylotrophs in the test system is justified. This combination makes it possible to select the effects of individual environmental factors in order to simplify the interpretation of the characteristics of the test object.

Based on the aforementioned, at this stage of the work we conducted a practical testing of the developed method of using indicators of the prooxidant-antioxidant system (PAS) of cultures of basidiomycetes in the bioindication of the state of the environment ${ }^{16,17}$.

The test objects were used strains of xylotrophic basidium fungi 960 A. cylindracea, P-er P. eryngii, P-089 P. ostreatus, Fh-08 F. hepatica and Sc-10 S. commune. The P-089, Fh-08 and Sc-10 strains are selected according to the following requirements: first, these are typical species of xylotrophic species in the study area; second, species have different systematic positions; third, the strains are well studied in culture and are characterized by high intensity of PAS processes both in mycelium and in the culture filtrate. The test strains P-er and 960 are atypical in the study area, but they have already been used in similar trials and there are interesting results for comparing the results of the biotesting in terms of the $K_{C}$ PAS.

The control strains were cultured periodically superficially in Erlenmeyer flasks with a capacity of $250 \mathrm{ml}$ per glucose peptone medium (GPM), $\left(\mathrm{pH}_{0} 6.5 \pm 0.2\right)$ in a volume of $50 \mathrm{ml}$. In the experiment, under the same

15 Чайка О.В., Федотов О.В. Оцінка екологічного стану довкілля 3 використанням прооксидантно-антиоксидантної активності культур базидіоміцетів. Біоресурси $i$ природокористування. 2014. № 6(1-2). C. 5-11. URL: http://journals.uran.ua/index.php/2078-9912/article/viewFile/114645/109117

${ }_{16}$ Федотов О.В. Інтенсивність процесів перекисного окиснення ліпідів штамів грибів порядків Agaricales i Polyporales. Вісник Дніпропетровського університету. Біологія, екологія. 2016. № 24(2). С. 314-323. DOI:10.15421/011641

17 Федотов О.В. Стан прооксидантно-антиоксидантної системи деяких штамів базидіомікотових грибів. Вісник Дніпропетровського університету. Біологія, медицина. 2017. № 8(1). C. 77-84. DOI: 10.15421/021714 
conditions, the glucose of the GPM was replaced by a plant substrate in an amount equivalent to the carbon content of glucose. Inoculum $\left(0.5 \pm 0.01 \mathrm{~g} / \mathrm{dm}^{3}\right)$ served 10 -day mycelium cultures of strains on CA. The cultivation period at $27.5^{\circ} \mathrm{C}$ was 12 days. The fermentation parameters are due to the technological and economic impracticality of long-term cultivation and the duration of the exponential growth phase of the strains.

After the strains were cultivated, indicators of their growth and PAS were determined and calculated.

As a plant substrate, the leaves of Tilia cordata Mill., a typical species of woody plant in the study area and in Ukraine as a whole, were used. The leaves were collected in the second part of the vegetation, after the end of active growth and before the fall. Separate growing middle-aged trees in similar conditions in terms of light, humidity, relief, soil conditions, etc., were selected for the experiment. The material was collected in dry weather. The leaves were taken at $2 \pm 0,1 \mathrm{~m}$ from the soil with the maximum number of branches available around the perimeter of the crown (from the southern, northern, eastern and western parts). For research selected 3-4 leaves of annual growth of lateral branches; one medium size; healthy, intact, without signs of chlorosis, etc. The material was collected from 8-10 trees at each location to obtain a medium-mixed sample. The freshly harvested plant substrate was washed with distilled water, dried at $20 \pm 5^{\circ} \mathrm{C}$. Then the substrate was fixed: kept for $15 \pm 2 \mathrm{~min}$ at $93 \pm 2^{\circ} \mathrm{C}$, while inactivating the vast majority of enzymes. The final removal of moisture was carried out in an oven at $45 \pm 5^{\circ} \mathrm{C}$ to constant weight of raw materials. The dried substrate was ground without heating to a flour state, carbon content was determined and used as a GPM component in the experiment.

Indicators of the state of the prooxidant-antioxidant system of the studied cultures - PAS balance coefficients $\left(K_{C}\right.$ PAS $)$, calculated on the values of spontaneous and induced intensity of lipid peroxidation (LP) processes, general antioxidant activity, level of prooxidant activity and substrate peroxide oxidation, are presented in the table 2.

In the course of the study, bioindication areas were selected - equidistant collection sites of plant substrate (location) in Vinnytsia, are significantly different by environmental factors: location 1 was located at the intersection of Kotsyubynsky street and Zamostyanskaya street (locally close to industrial enterprises, one of the main transport interchanges); location $2-$ Keletska street and Pirogova street (one of the main transport interchanges of the city); location 3 - Andriya Pervozvannogo street and Yunosti street (residential area of neighborhood of the city); location $4-$ st. Chernyakhovsky and Pryuzhsky alley (environmental protection area, natural background - NB).

The results of the experiment showed that the test-objects accumulate biomass (absolutely dry biomass - ADB) equally well on all modifications 
of the medium with plant substrates. No significant difference in the level of ADB accumulation within the strain was found between locations.

Table 2

\section{Balance coefficients of prooxidant-antioxidant system of mycelium and CF of basidiomycete's strains in bioindication of the state of the environment of Vinnitsa}

\begin{tabular}{|c|c|c|c|c|c|c|}
\hline \multirow[b]{2}{*}{ Location } & \multirow{2}{*}{$\begin{array}{l}\text { ADB, } \\
\text { g/dm }\end{array}$} & \multirow[b]{2}{*}{ NB \% } & \multicolumn{4}{|c|}{$K_{C P A S}$} \\
\hline & & & Mycelium & $\begin{array}{c}\text { NB } \\
\%\end{array}$ & $\mathbf{C F}$ & $\begin{array}{c}\text { NB } \\
\%\end{array}$ \\
\hline \multicolumn{7}{|c|}{ Strain 960 A. cylindracea } \\
\hline 1 & $11.82 \pm 0.61$ & 99 & $48.09 \pm 2.03 *$ & 65 & $15.64 \pm 1.50 *$ & 64 \\
\hline 2 & $12.14 \pm 0.49$ & 102 & $56.10 \pm 2.05 *$ & 76 & $15.73 \pm 1.13 *$ & 65 \\
\hline 3 & $11.97 \pm 0.36$ & 102 & $74.00 \pm 1.81$ & 100 & $17.03 \pm 1.09 *$ & 70 \\
\hline $4(\mathrm{NB})$ & $11.91 \pm 0.23$ & 100 & $73.79 \pm 2.98$ & 100 & $24.31 \pm 1.31$ & 100 \\
\hline \multicolumn{7}{|c|}{ Strain P-er P. eryngii } \\
\hline 1 & $5.31 \pm 0.22$ & 102 & $43.00 \pm 3.03 *$ & 59 & $20.23 \pm 1.03 *$ & 71 \\
\hline 2 & $5.40 \pm 0.20$ & 105 & $43.84 \pm 2.64 *$ & 60 & $20.81 \pm 2.09 *$ & 73 \\
\hline 3 & $5.31 \pm 0.19$ & 102 & $58.00 \pm 1.50 *$ & 81 & $21.00 \pm 0.91 *$ & 73 \\
\hline $4(\mathrm{NB})$ & $5.25 \pm 0.25$ & 100 & $72.48 \pm 2.19$ & 100 & $28.69 \pm 0.89$ & 100 \\
\hline \multicolumn{7}{|c|}{ Strain P-089 P. ostreatus } \\
\hline 1 & $3.45 \pm 0.56$ & 105 & $41.09 \pm 1.26 *$ & 82 & $18.64 \pm 1.27^{*}$ & 80 \\
\hline 2 & $3.46 \pm 0.67$ & 105 & $40.62 \pm 2.97 *$ & 76 & $18.73 \pm 1.08 *$ & 80 \\
\hline 3 & $3.31 \pm 0.12$ & 101 & $55.12 \pm 1.63$ & 102 & $25.13 \pm 0.97$ & 107 \\
\hline $4(\mathrm{NB})$ & $3.29 \pm 0.09$ & 100 & $53.79 \pm 2.48$ & 100 & $23.31 \pm 1.61$ & 100 \\
\hline \multicolumn{7}{|c|}{ Strain Fh-08 F. hepatica } \\
\hline 1 & $3.30 \pm 0.19$ & 102 & $10.99 \pm 3.03 *$ & 34 & $12.23 \pm 0.57 *$ & 59 \\
\hline 2 & $3.40 \pm 0.20$ & 105 & $11.84 \pm 2.64 *$ & 37 & $12.81 \pm 0.09 *$ & 62 \\
\hline 3 & $3.31 \pm 0.09$ & 102 & $30.57 \pm 1.50$ & 94 & $16.34 \pm 0.68 *$ & 79 \\
\hline $4(\mathrm{NB})$ & $3.25 \pm 0.15$ & 100 & $32.48 \pm 1.09$ & 100 & $20.69 \pm 0.87$ & 100 \\
\hline \multicolumn{7}{|c|}{ Strain Sc-10 S. commune } \\
\hline 1 & $3.55 \pm 0.25$ & 102 & $64.08 \pm 0.98 *$ & 84 & $31.65 \pm 0.05 *$ & 94 \\
\hline 2 & $3.71 \pm 0.18$ & 106 & $66.67 \pm 1.24 *$ & 88 & $31.01 \pm 0.11 *$ & 92 \\
\hline 3 & $3.67 \pm 0.21$ & 105 & $72.56 \pm 1.34$ & 95 & $32.45 \pm 0.05$ & 96 \\
\hline $4(\mathrm{NB})$ & $3.49 \pm 0.14$ & 100 & $76.12 \pm 2.61$ & 100 & $33.64 \pm 2.02$ & 100 \\
\hline
\end{tabular}

Note. $\left\langle * *^{*}\right.$-difference is valid compared to location 4

Analysis of the indicators of the prooxidant-antioxidant system of selected xylotrophic strains proves the following.

The $K_{C}$ PAS level of the selected test-objects showed a reliable dependence of fixed values on the place of collection of the plant substrate. When testing objects are cultivated on modifications of GPM containing plants substrates of Locations 1 and 2 (in our opinion, with high technogenic load), there is a reliable increase of spontaneous indicators of intensity of the processes of LP in the mycelium. This leads to an increase in POA of the mycelium and, corresponding decrease in inactive spontaneous peroxidation 
(SP). As a result, the calculation of the $K_{C}$ PAS indicators shows their decrease and the shift of the balance of the PAS towards oxidation as compared to location 4.

The compensatory increase in AOA of mycelium and CE was recorded for strain P-089 (location 3), which can be considered as an overcompensation phenomenon and indicates the stability of homeostasis of the test-object under these fermentation conditions. The decrease in $K_{C}$ PAS in the vast majority of cases indicates the absence of a compensatory increase in AOA in the mycological material and the shift of $K_{C}$ PAS indicators towards prooxidation.

Thus, the results of practical testing of the use of indicators of the prooxidant-antioxidant system of cultures of basidiomycetes in bioindication of the state of the environment make it possible to confirm the following.

Test-objects - strains of xylotrophic basidium fungi 960 A. cylindracea, P.-er P. eryngii, P-089 P. ostreatus, Fh-08 F. hepatica and Sc-10 $S$. commune equally well accumulate biomass on standard and modified GPM with plant substrate.

The cultivation of test-objects on modified GPM containing a plant substrate of locations with high technogenic load leads to a probable shift of the PAS balance toward prooxidation. In the proposed method of biotesting the environmental condition, both test species and species that do not grow in the test area and exhibit good growth rates on GPM with a plant substrate may be used as test objects.

For the P-089 strain, an adaptive compensatory increase of AOA mycelium and CF has been recorded, which may limit its use as a test object due to the high protective potential of this mycelial culture Pleurotus ostreatus. Cultures with compensatory potential and high biosynthetic properties are promising for use in biodegradation and biorecycling technologies for certain industrial and agricultural wastes.

\section{Development of a method of bioconversion of lignocellulosic waste using basidium mushrooms carotenoids producers}

To date, lignocellulose waste is not recycled, incinerated or disposed without recycling, and is an environmentally hazardous disposal method. Wood destroying basidiomycetes (xylotrophs) are characterized by wood substrate and various plant residues that contain lignocellulose.

Providing livestock with a prey base is an actual task for its development. The bioconversion of plant wastes through the enrichment of protein and other fungal substances by the development of xylotrophs on them allows an increase in the quantity of feed and an improvement in its quality. One way of bioconverting such waste into nutrient enriched by mushrooms feed mikorm (MK) is through solid-phase fermentation (SPF) of basidiomycetes. The essence of solid-phase fermentation is the cultivation of somatic structures of micellar tree-destroying mushrooms on grounded lignocellulose substrates. 
Research focuses on the mechanisms for splitting lignocellulose of treedestroying mushrooms, as it is assumed knowledge of these mechanisms may open ways for the development of environmentally friendly energysaving biotechnologies for wood processing and various plant wastes.

There are known methods of recycling of plant waste production of palm oil by processing them into lignocellulosic flour, and then using it to produce liquid and solid fuels. The methods are developed for another type of raw material and do not contain bioconversion technology 18,19 .

The modern achievements in the field of recycling lignocellulosic raw materials are reviewed, the prospects of using this raw material as fertilizer are shown. The results of research on the development of composting method for hydrolysis of lignin and sawdust, the evaluation of the quality of the final product. The review does not include bioconversion technologies for lignocellulosic wastes using basidiomycetes strains.

The method of growing the oyster mushroom is the closest to the technical nature and the reach of the result. The method involves the preparation and heat treatment of lignocellulosic waste from agriculture and forestry, seeded mycelium in the substrate in perforated packages with slots. After sowing the mycelium in the substrate on the perforated package put on the second package with a micro perforation with a diameter of $0.1-0.3 \mathrm{~cm}$ at a distance of $10-15 \mathrm{~cm}$ during the incubation period and when the first germ of fruiting bodies, the second package is removed. The method is designed for other types of mushroom and raw materials.

Based on the above, at this stage of the work was carried out a practical test of the developed method of bioconversion of lignocellulosic waste oil processing oil (LORW: sunflower husk, rapeseed, etc.) by solid-phase fermentation (SPF) of the basidium mushroom Laetiporus sulphureus (Bull.) Murrill - which are the carotenoid producer ${ }^{20,21}$.

The choice of SPF is explained by the fact that fermentation in fermenters is characterized by higher energy costs for nutrient preparation, aeration, mixing of crop fluid, separation and biomass dehydration, which are the determinants of the cost price of the final product, which limit its production. Another factor limiting production - the cost of raw materials, also explains the choice of lignocellulosic waste processing oilseeds.

We have justified the perspective of biotechnological use of xylotrophic L. sulphureus, which showed high biosynthetic properties: it has carotenoids

18 Fedotov O.V., Velygodska A.K. Search producers of polyphenols and some pigments among Basidiomycetes. Biotechnologia Acta. 2014. № 7(1). P. 110-116.

19 Велигодська А.К., Федотов О.В. Порівняльна характеристика загального вмісту каротиноїдів у деяких видів базидіальних грибів. Мікробіологія $i$ біотехнологія. 2012. № 4(20). C. 84-101. URL: http://dx.doi.org/10.7905/bbmspu.v4i1.788

20 Велигодська А.К., Федотов О.В. Порівняльна характеристика загального вмісту каротиноїдів у деяких видів базидіальних грибів. Мікробіологія $і$ біотехнологія. 2012. № 4(20). C. 84-101. URL: http://dx.doi.org/10.7905/bbmspu.v4i1.788

${ }^{21}$ Велигодська А.К., Федотов О.В. Отримання та аналіз препаратів каротиноїдів деяких штамів ксилотрофних базидіоміцетів. Вісник Дніпропетровського університету. Біологія, екологія. 2016. № 24(2). С. 290-294. DOI:10.15421/011637 
content in mycelium - up to $5.13 \mathrm{mg} / \mathrm{g}$ and in crops filtrate - up to $0.13 \mathrm{mg} / \mathrm{ml}$ on the 12th day when cultured on glucose-peptone medium.

The developed method of bioconversion of lignocellulosic waste processing oilseeds consists of 5 stages.

Step 1 - obtaining a suspension of sowing mycelium. Mycelium of strain Ls08 L. sulphureus was grown on wort agar (WA, 4 by Balling) and maintained by transplanting. To obtain the inoculum, 10 day WA mycelium crops in a volume of $5 \mathrm{~mm}^{3}$ were aseptically transferred and cultivated in $250 \mathrm{ml}$ Erlenmeyer flasks per $100 \mathrm{ml}$ standard composition GPS. Seed mycelium was grown for 12 days at $27.5^{\circ} \mathrm{C}$ and mixing. The optimal mode of cultivation was determined experimentally.

Step 2 - Grinding and wetting of lignocellulosic waste. The lignocellulosic waste from oilseed processing was mechanically shredded to the optimum particle sizes of the substrate $4 \pm 2 \mathrm{~mm}$. The obtained substrate was moisturizing with tap water in a ratio of 1:4 weight parts in accordance with humidity of $65-75 \%$. This treatment provides an increase in the surface of the substrate particles and better access to the growing mycelium and exoenzymes to the power sources: intensive destruction, digestion and conversion of lignocellulosic substrate to mycological feed - mikorm (MK).

Step 3 - substrate sterilization. The lignocellulosic substrate was transferred to the cultivation containers in an amount appropriate to the cultivation task. The containers or directly the raw material was placed in an autoclave and sterilized for $40-60 \mathrm{~min}$. (directly proportional to the volume of the substrate) at $121 \pm 2^{\circ} \mathrm{C}$. At large volumes pasteurization of wet raw materials at $100^{\circ} \mathrm{C}$ for $1-2$ hours is possible. The substrate particles thus significantly increase due to changes in the internal structure.

Step 4 - inoculation and cultivation of the mycelium of the mushroom L. sulphureus on the substrate. After sterilization, the substrate was placed in a sterile box, passively cooled and inoculated at the rate of 3:1 mycelial suspension. The cultivation period (overgrowth of the mycelium substrate) was 7-10 days at $27.5 \pm 2{ }^{\circ} \mathrm{C}$. Due to the fact that the temperature of cultivation affects the cost of the product and increases by $1-2^{\circ} \mathrm{C}$ in the middle of the substrate layer. During the SPF, the substrate was penetrated through lush and felt mycelium without spoilage.

Step 5 - preparation of the final product. For further storage and use, the final product was crushed or granulated and dried dry heat cabinet at $70 \pm 5^{\circ} \mathrm{C}$.

Analysis of the chemical composition of lignocellulosic waste oilseed processing and the obtained mykorm shows the following. In MK compared to the original substrate increased protein content by 1.8-2.0 times, including the content of digestible protein $-2.2-2.9$ times. The content of gluten decreased by 1.5-1.9 times; the amount of nitrogen-free extractive substances increased by 1.2-1.5 times. Due to the presence in the GPM, the calcium content increased by $1.4-1.6$ times and phosphorus by 1.1-1.3 times. The content of carotenoids in MK increased significantly - from traces to $3.5-4.1 \mathrm{mg} / \mathrm{g}$. At the same time, the presence of plant oils in MK decreased by 1.8-2.1 times, which can be 
explained by the consumption of mushroom culture and considerable volatility in heating the substrate.

For the characterization of biological quality, the method of chemical equivalent - comparison of composition of essential amino acids of experimental and ideal protein was applied. The scale recommended by the Joint (Food and Agriculture Organization, FAO) FAO/WHO Expert Committee was used. An amino acid having a minimal amino acid equivalent limits the biological value of the protein. The quantitative content of amino acids and protein in the substrate and mykorm was determined using an amino acid analyzer, hydrolysis was acidic. $\mathbf{S}$ - is the highest level of amino acid content of the ideal protein, $\mathrm{C}$ - is the amino acid content of the sample protein (Table 3 ).

According to the research, the biological value of the protein in the samples of lignocellulosic waste from oilseed crop and mykorm differs significantly.

Thus, the content of such essential amino acids as methionine, cysteine, phenylalanine and tyrosine significantly exceeds the required level of amino acid content in the ideal protein, and the content of isoleucine and threonine is close to it. The quantity of these amino acids in LORW is only $60-80 \%$ compliant with the requirements of the FAO/WHO standard. The total quantity of mykorm amino acids is 1.6 times greater than in lignocellulosic waste. The value of mykorm protein is limited by the leucine content of $55.7 \%$, which is slightly higher than the wheat protein, whose value is in the range of $53-55 \%$. The biological value of the LORW protein is limited by the lysine content and is at $51.8 \%$. This protein is characterized by an imbalance in the amino acid composition, which also reduces the biological value ${ }^{22}$.

Table 3

Amino acid equivalent to mykorm (MK) proteins and lignocellulosic oilseed recycling waste (LORW)

\begin{tabular}{|c|c|c|c|c|c|c|}
\hline \multirow[b]{2}{*}{ № } & \multirow[b]{2}{*}{ Amino acids } & \multirow{2}{*}{$\begin{array}{c}\mathrm{S}, \\
\mathrm{mg} / \mathrm{g}\end{array}$} & \multicolumn{2}{|c|}{ MK } & \multicolumn{2}{|c|}{ LORW } \\
\hline & & & $\begin{array}{c}\mathrm{C}_{1}, \\
\mathrm{mg} / \mathrm{g}\end{array}$ & $\begin{array}{c}C_{1} / S \\
\times 100 \%\end{array}$ & $\begin{array}{c}\mathrm{C}_{2}, \\
\mathrm{mg} / \mathrm{g}\end{array}$ & $\begin{array}{c}\mathrm{C}_{2} / \mathrm{S} \\
\times 100 \%\end{array}$ \\
\hline 1. & Ile, I* & 40 & $38.56 \pm 1.55$ & 96.37 & $22.10 \pm 2.85$ & 55.25 \\
\hline 2. & Leu, L* & 70 & $38.98 \pm 1.19$ & 55.70 & $41.58 \pm 2.13$ & 59.41 \\
\hline 3. & Lys, $K^{*}$ & 55 & $41.97 \pm 2.13$ & 76.30 & $28.52 \pm 0.44$ & 51.80 \\
\hline 4. & Met, $M *+$ Cys, C & 35 & $76.33 \pm 2.18$ & 218.0 & $30.60 \pm 1.34$ & 87.42 \\
\hline 5. & Phe, F* + (Tyr, Y & 60 & $96.84 \pm 1.36$ & 161.35 & $38.87 \pm 1.67$ & 64.76 \\
\hline 6. & Thr, T* & 40 & $33.98 \pm 0.89$ & 84.97 & $31.54 \pm 1.34$ & 78.85 \\
\hline 7. & Trp, W ** & 10 & - & - & - & - \\
\hline 8. & Val, V* & 50 & $33.57 \pm 1.49$ & 67.16 & $27.59 \pm 1.09$ & 55.16 \\
\hline & Total: & 360 & 360.23 & - & 220.80 & - \\
\hline
\end{tabular}

Note: “*”-indispensable amino acids, (in parentheses) - abbreviation, “**”-amino acids, whose content was not determined; "Underlined" - the value of the minimum amino acid equivalent, which limits the biological value of the protein

22 Федотов О.В. Біотехнологічні засади регулювання і використання прооксидантно-антиоксидантної активності базидієвих грибів : дис. ... д-ра біол. наук : 03.00.20. Київ, 2018. 327 с. 
Thus, the proposed method of bioconversion of lignocellulosic waste recycling oilseeds by growing on them strains of the tree-destroying basidium mushrooms Laetiporus sulphureus allows to convert various types of plant raw materials and its waste into feed additives with increased content of valuable proteins and biologically active substances, biologically active substances leading to simplification, greening and cheaper production $^{23}$.

\section{Development of a method for biodegradation of organic compounds formed by oxidation of aniline using basidium mushroom - producers of peroxidases and prooxidant compounds}

The presence of high concentrations of chemical pollutants in the wastewater from certain industrial and agricultural economics make difficulties in their purification. For example, micro-organisms of active sludge of biological sewage treatment plant are productive in the process purification of domestic wastewater and are ineffective in neutralization of xenobiotics. So the development of modern methods of destruction of chemically resistant compounds is relevant.

It is promising to find and use new organisms (including mycologic ones) that are resistant to xenobiotics.

Highly toxic aniline synthetic dyes used for colouring products, preparations and fabrics are one of the main types of contaminants in the textile and food industries and medicine. The toxic effect of these dyes complicates (or makes impossible at high concentrations) their microbiological degradation. However, studies have shown that aniline is a peroxidase substrate. The enzyme is able to oxidize it to nitrobenzene, which is easily subjected to further complete detoxification.

Basidium mushroom Pleurotus ostreatus has been extensively studied and is promising in biotechnology for the production of commercial fruiting bodies and physiologically active substances. Screening studies have shown the possibility of using strain P-01 P. ostreatus as a highly active producer of extra- and intracellular peroxidases in the biotechnology of mycological peroxidase enzyme production ${ }^{24}$.

Recently patented developments on the use of biological agents for the purification of environmental objects and destruction of xenobiotics. There is a known method of biological purification of wastewater from phenol. Purification is carried out by the joint and simultaneous oxidation of phenols with activated sludge and hydrogen peroxide. The method of sewage

23 Федотов О.В. Біотехнологічні засади регулювання i використання прооксидантно-антиоксидантної активності базидієвих грибів : дис. ... д-ра біол. наук : 03.00.20. Київ, 2018. 327 с.

${ }^{24}$ Fedotov O.V., Bisko N.A. Effect of Phenolic Substances and Hydrogen Peroxide on Antioxidant Activity of Some Strains of Basidiomycetes. Innovative Biosystems and Bioengineering. 2018. 1(2). P. 4-10. URL: https://doi.org/10.20535/ibb.2018.2.1.124101 
treatment from dyes and/or organic substances containing sulphide groups was tested. Wastewater is treated at $\mathrm{pH} 9.5-11.5$ with water-soluble salt of two or trivalent metal in a mass ratio of ingredients $4: 1-15: 1$, neutralized to $\mathrm{pH}$ 6.5-8.5 and subjected to mechanical purification with subsequent ultrafiltration separation. A method of purification of environmental objects from petroleum products has been developed. New bacterial strains are being used - petroleum product destructors capable of growing over a wide range of temperatures and $\mathrm{pH}$, as well as at elevated temperatures in environments containing n-paraffins of a broad fraction, diesel, crude oil, fuel oil, aromatic carbon as a carbon source. The strains can be used for purification from oil pollution of different container, water surfaces, soils, sewage of oil refining, metallurgical, machine building, food industry, in the production of soaps, paints, perfumes and cosmetics. The essence of the application: obtaining biological products based on strains of Acinetobacter valentis subspecies paraffinicum, growing at a temperature of $10-50^{\circ} \mathrm{C}$, in a wide $\mathrm{pH}$ range of 5.5-8.5 at a flow rate of the medium $\mathrm{D}=0.25-0.33 \mathrm{~h}^{-1}$.

The basis of this step of research is the task of developing and testing in the laboratory conditions of the method of destruction of aniline dye (CI 27950) using the highly active strain P-01 P. ostreatus, which is new to the body-destructor, cheap and affordable in technology when used in treatment plants industrial enterprises whose waste contains this dye.

The developed method of biodegradation of organic compounds formed by aniline oxidation includes 3 steps.

Step 1 - Cultivation of the destructor strain on a standard medium. Strain P-01 of P. ostreatus was cultivate on GPM under standard conditions, where the ratio $\mathrm{C}: \mathrm{N}$ is 13:1. As the inoculum used 10-day mycelial cultures of strain P-01 on agar wort.

Step 2 is the cultivation of a destructor strain on medium with different concentrations of aniline dye. It is known that the wastewater of the textile industry contains aniline dye (C.I. 27950) at a concentration of $0.2865 \pm 0.01$ $\mathrm{g} / \mathrm{dm}^{3}$. On this basis, aniline dye (C.I. 27950) was added to the standard GPM at concentrations of 0.2865 ; as well as 0.1433 ; 0.0573 and 0.0287 $\mathrm{g} / \mathrm{dm}^{3}$, reaching a dilution of the basic concentration by 2,5 and 10 times. Further, on the resulting modifications of the GPS was cultivated strain P-01 P. ostreatus. The 12-day period and the fermentation temperature of $27.5^{\circ} \mathrm{C}$ were selected based on the results of previous studies, which revealed that PA maxima accounted for the exponential growth period of strain P-01.

At the end of the cultivation period peroxidase activity was determined in the mycelium and culture filtrate, the accumulation of ADB and the rate of destruction of the aniline dye (Table 4). The concentration of polutant, the accumulation of $\mathrm{ADB}$, the initial $\left(\mathrm{pH}_{0}\right)$ and end $\left(\mathrm{pH}_{12}\right)$ fermentation of the $\mathrm{pH}$ of the culture fluid, the level of specific PA and the efficiency of dyeing of the dye. 
Research has shown that aniline dye at all concentrations inhibits the rate of biomass accumulation by $P$. ostreatus strain P-01. An exception is the concentration of $0.0287 \mathrm{~g} / \mathrm{dm}^{3}$, in which the ADB is not significantly different from the control.

Table 4

Peroxidase activity and decolorization efficiency of aniline dye

(C.I. 27950) by strain P-01 of $P$. ostreatus

\begin{tabular}{|c|c|c|c|c|c|c|}
\hline \multirow{2}{*}{ 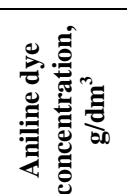 } & \multirow[b]{2}{*}{$\mathrm{pH}_{0}$} & \multirow[b]{2}{*}{$\mathrm{pH}_{12}$} & \multirow[b]{2}{*}{$\begin{array}{l}\text { ADB, } \\
\text { g/dm }\end{array}$} & \multicolumn{2}{|c|}{$\mathbf{P A}_{\mathrm{s}}$, a.u./mg 10 } & \multirow[b]{2}{*}{ E, \% } \\
\hline & & & & Mycelium & CF & \\
\hline 0.2865 & 6.52 & $6.95^{*}$ & $2.68 \pm 0.07^{*}$ & $1.25 \pm 0.05^{*}$ & $1.06 \pm 0.12$ & $38.35 \pm 1.02$ \\
\hline 0.1433 & 6.50 & $6.68^{*}$ & $3.20 \pm 0.09^{*}$ & $1.38 \pm 0.15^{*}$ & $1.85 \pm 0.30^{*}$ & $50.10 \pm 0.85$ \\
\hline 0.0573 & 6.50 & $6.35^{*}$ & $3.20 \pm 0.05^{*}$ & $1.00 \pm 0.11^{*}$ & $1.50 \pm 0.01 *$ & $60.78 \pm 1.04$ \\
\hline 0.0287 & 6.48 & 6.26 & $3.50 \pm 0.05$ & $1.00 \pm 0.05^{*}$ & $1.27 \pm 0.03^{*}$ & $85.80 \pm 1.05$ \\
\hline 0 (control) & 6.50 & 6.20 & $3.55 \pm 0.02$ & $0.44 \pm 0.02$ & $0.92 \pm 0.06$ & - \\
\hline
\end{tabular}

Note: $" *$ - difference is valid compared to controle

The peroxidase of the mycelium activity, when compared to the control, is probably increased by the action of the aniline dye at all concentrations. The maximum level of peroxidase activity specific $\left(\mathrm{PA}_{\mathrm{s}}\right)$ mycelium and culture filtrate was fixed at a concentration of $0.1433 \mathrm{~g} / \mathrm{dm}^{3}$.

The bleaching efficiency of aniline dye (C.I. 27950) is maximum at the lowest dye concentration in the medium. With increasing concentration there is a decrease in the efficiency of discoloration, which is consistent with the growth rates.

In step 3, the destruction of the aniline dye (C.I. 27950) in aqueous solution was studied by adding the mycelium of $P$. ostreatus strain P-01 (Table 5).

An aqueous solution of aniline dye (C.I. 27950) was prepared at a concentration of $0.0287 \mathrm{~g} / \mathrm{dm}^{3}$ - the concentration corresponds to the highest level of bleaching efficiency. To the solution was made congenital mycelium of strain R-01 P. ostreatus in the amount of $1.0 ; 1.5 ; 2.0 ; 2.5$ and $3.0 \mathrm{~g} / \mathrm{dm}^{3}$ in terms of ADB. The mixture was incubated for 1,2 and 3 days under standard conditions. At the end of cultivation was determined by the effectiveness of the dye discoloration.

The study of the bleaching efficiency of an aqueous solution of aniline dye (C.I. 27950) at a concentration of $0.0287 \mathrm{~g} / \mathrm{dm}^{3}$ when applying the mycelium of strain $P$. ostreatus P-01, showed the following. There is a gradual increase in the $\mathrm{E}$, with an increase in both the exposure time and the amount of mycelium introduced. The maximum bleaching efficiency $75.9 \%$ - corresponds to the maximum effect of the factors. 
Thus, the proposed method for the destruction of aniline dye (C.I. 27950) using strain P-01 P. ostreatus is new to the organism-destructor, cheap and affordable technology for use in sewage treatment works of industrial enterprises, the waste of which contains organic compounds - oxidized aniline. The type of basidium mushrooms used in the method is a typical, widespread edible, which makes it impossible for microbiological pollution.

Table 5

The bleaching efficiency of aniline dye (C.I. 27950) at a concentration of $0.0287 \mathrm{~g} / \mathrm{dm}^{3}$ mycelium of strain P-01, depending on the exposure time of the mycelium

\begin{tabular}{|c|c|c|c|c|c|}
\hline \multirow{2}{*}{$\begin{array}{c}\text { Exposition, } \\
\text { hours }\end{array}$} & \multicolumn{5}{|c|}{ The quantity of mycelium (ADB), $\mathbf{g} / \mathbf{d m}^{3}$} \\
\cline { 2 - 6 } & 1.0 & 1.5 & 2.0 & 2.5 & 3.0 \\
\hline 24 & $19.50 \pm 0.50$ & $25.24 \pm 0.62$ & $35.50 \pm 0.95$ & $45.12 \pm 1.01$ & $58.90 \pm 1.30$ \\
\hline 48 & $23.45 \pm 0.25$ & $34.88 \pm 0.81$ & $46.85 \pm 0.25$ & $55.20 \pm 1.05$ & $68.56 \pm 1.30$ \\
\hline 72 & $30.00 \pm 1.01$ & $45.20 \pm 0.80$ & $50.09 \pm 1.03$ & $66.56 \pm 1.03$ & $75.90 \pm 1.45$ \\
\hline
\end{tabular}

\section{CONCLUSIONS}

Therefore, semi-production and production tests of methods of practical use of the prooxidant-antioxidant system of introduced strains of medicinal basidium mushrooms in biotechnology: production of oxidoreductases, establishment of antioxidant activity of enzyme preparations, bioconversion of lignocellulosic wastewaters - effectiveness of the proposed methods and approaches that ensure the production of new products quality diagnosis and intensification of biotechnological production ${ }^{25}$.

\section{SUMMARY}

Thus, the results of the development and testing of biotechnological methods of using the prooxidant-antioxidant properties of strains of medicinal mushrooms allow us to state the following. Methods for the practical use of prooxidant-antioxidant activity of basidium mushrooms in biotechnology were first developed and worked out: oxidoreductases produced and recommended producers of antioxidants, bioconversion of lignocellulosic wastes use the strains - carboninoids producers, biodestruction of organic compounds - aniline derivatives, etc.

\section{REFERENCES}

1. Велигодська А.К., Федотов О.В. Отримання та аналіз препаратів каротиноїдів деяких штамів ксилотрофних базидіоміцетів. Вісник

25 Федотов О.В. Біотехнологічні засади регулювання і використання прооксидантно-антиоксидантної активності базидієвих грибів : дис. ... д-ра біол. наук : 03.00.20. Київ, 2018. 327 с. 
Дніпропетровського університету. Біологія, екологія. 2016. № 24(2). C. 290-294. DOI:10.15421/011637

2. Велигодська А.К., Федотов О.В. Порівняльна характеристика загального вмісту каротиноїдів у деяких видів базидіальних грибів. Мікробіологія $і$ біотехнологія. 2012. № 4(20). С. 84-101. URL: http://dx.doi.org/10.7905/bbmspu.v4i1.788

3. Федотов О.В. Амінокислотний склад ферментних препаратів каталази їстівних лікарських грибів Flammulina velutipes i Pleurotus ostreatus. Вісник Донецького університету. Сер. А: Природничі науки. 2005. № 2. C. 247-250.

4. Федотов О.В. Амінокислотний склад ферментних препаратів пероксидаз їстівних лікарських грибів Lentinus edodes, Flammulina velutipes i Pleurotus ostreatus. Вісник Донеиького університету. Сер. А: Природничі науки. 2006. № 2. С. 270-274.

5. Федотов О.В. Біотехнологічні засади регулювання i використання прооксидантно-антиоксидантної активності базидієвих грибів : дис. ... д-ра біол. наук : 03.00.20. Київ, 2018. 327 с.

6. Федотов О.В. Інтенсивність процесів перекисного окиснення ліпідів штамів грибів порядків Agaricales i Polyporales. Вісник Дніпропетровського університету. Біологія, екологія. 2016. № 24(2). C. 314-323. DOI: $10.15421 / 011641$

7. Федотов О.В. Стан прооксидантно-антиоксидантної системи деяких штамів базидіомікотових грибів. Вісник Дніпропетровського університету. Біологія, медииина. 2017. № 8(1). C. 77-84. DOI: $10.15421 / 021714$

8. Федотов О.В. Фізико-хімічні показники мікологічних об'єктів у біоіндикації довкілля. Проблеми екології та охорони природи техногенного регіону. 2011. № 1(11). С. 261-265.

9. Федотов О.В., Волошко Т.Є. Розробка способів отримання і аналіз ферментних препаратів пероксидаз та каталаз деяких видів базидіоміцетів. Біологічний вісник Мелітопольського державного педагогічного університету ім. Богдана Хмельнииького. 2013. № 1(7). C. 113-127. URL: http://nbuv.gov.ua/UJRN/bvmd_2013_1_12

10. Федотов О.В., Євсєєнкова А.М., Перцевой М.С. Активність ПОЛ i каталази макроміцетів - як можливі біоіндикаційні показники екологічного стану їх місця зростання. Збірник наукових пращь Луганського національного аграрного університету. Сер. «Сільськогосподарські науки». 2008. № 82. С. 73-81.

11. Федотов О.В., Чайка О.В., Волошко Т.С., Велигодська А.К. Колекція культур шапинкових грибів - основа мікологічних досліджень та стратегії збереження біорізноманіття базидіоміцетів. Вісник Донецького університету, Сер. А: Природничі науки. 2012. № 1. C. 209-213. URL: http://jvestnik-a.donnu.edu.ua/article/viewFile/4991/5024 
12. Федотов О.В. Загальна антиоксидантна активність деяких штамів базидіальних грибів в динаміці росту. Біологічний вісник Мелітопольського державного педагогічного університету ім. Богдана Хмельницького. 2016. № 2(6). С. 158-165.

13. Чайка О.В., Федотов О.В. Оцінка екологічного стану довкілля 3 використанням прооксидантно-антиоксидантної активності культур базидіоміцетів. Біоресурси $і$ природокористування. 2014. № 6(1-2). C. 5-11. URL: http://journals.uran.ua/index.php/2078-9912/article/viewFile/ $114645 / 109117$

14. Fedotov O.V., Velygodska A.K. Milk-clotting and antioxidant activity of enzyme preparations of fungi strains of the order Polyporales s.l. The scientific heritage. Biological Sciences. 2016. V. 1. 2(2). P. 71-76.

15. Fedotov O.V., Velygodska A.K. Search producers of polyphenols and some pigments among Basidiomycetes. Biotechnologia Acta. 2014. № 7(1). P. 110-116.

16. Fedotov O.V., Bisko N.A. Effect of Phenolic Substances and Hydrogen Peroxide on Antioxidant Activity of Some Strains of Basidiomycetes. Innovative Biosystems and Bioengineering. 2018. № 1(2). P. 4-10. URL: https://doi.org/10.20535/ibb.2018.2.1.124101

17. Voloshko T.E., Fedotov O.V. Comparative characteristics of basidiomycetes - producers of catalase. Biotechnologia Acta. 2013. № 6(3). P. 89-94.

18. Voloshko T.E., Fedotov O.V. Active producers of peroxidase Basidiomycetes strains screening. Biotechnologia Acta. 2013. № 6(5). P. 137-142. URL: http://oaji.net/articles/2017/5931-1520253769.pdf

\section{Information about authors: Fedotov O. V.,}

Doctor of Biological Sciences, Senior Researcher, Associate Professor, Head of the Department of Medical Biology Donetsk National Medical University 27, Railway Station str., Lyman, Donetsk region, 84404, Ukraine

Usikova Z. L., Senior Lecturer of the Department of Medical Biology Donetsk National Medical University 27, Railway Station str., Lyman, Donetsk region, 84404, Ukraine 